\title{
School of Education
}

Te Kura Toi Tangata

\section{Waikato Journal of Education}

Te Hautaka Mātauranga o Waikato

Volume 13: 2007

Special Issue on Creative Research in the Arts 


\section{WAIKATO JOURNAL OF EDUCATION \\ TE HAUTAKA MĀTAURANGA O WAIKATO \\ Editors: \\ Toni Bruce \\ Rosemary De Luca \\ Special Edition Editor \\ Karen Barbour \\ Editorial Board: \\ Miles Barker \\ Margaret Carr \\ Deborah Fraser \\ Alan Hall \\ Clive McGee \\ Judy Moreland \\ Clive Pope}

Waikato Journal of Education is a refereed journal, published annually, based in the School of Education, University of Waikato, Hamilton, New Zealand. It publishes articles in the broad field of education. For further information visit the WJE website http:/www.soe.waikato.ac.nz/wje/

Correspondence should be addressed to: Rosemary De Luca, Editor, School of Education, Private Bag 3105, The University of Waikato, Hamilton, New Zealand. Email: deluca@waikato.ac.nz

Books for review should be sent to the Editors.

Business correspondence: Orders, subscription payments and other enquiries should be sent to the Business Manager, Waikato Journal of Education, Wilf Malcolm Institute of Educational Research, School of Education, The University of Waikato, Private Bag 3105, Hamilton, New Zealand.

\section{Subscriptions: $\quad$ Within NZ $\$ 35$; Overseas NZ \$45 \\ Copyright: $\quad$ (C) School of Education, The University of Waikato}

"Because of the unique nature of the 2007 special focus section on the arts, copyright of original artwork (such as paintings, poetry, dance video or images) will remain with the creator."
Publisher:
School of Education, The University of Waikato
Cover design:
Donn Ratana
Printed by:
Waikato Print

\section{Call for Papers \\ Special section 2008: New developments in curriculum. Submission Deadline: 30 October, 2008}

This special section focuses on new developments in curriculum, a topic of current interest in view of the introduction of the new New Zealand curriculum in 2007. The new curriculum calls for creative responses from teachers, teacher educators and others interested in the material and content of teaching. For the first time in New Zealand, pedagogy has been included in an account of the school curriculum, so the editors welcome any papers which reflect interaction between curriculum and pedagogy as well as subjectoriented or content-focused papers. 


\title{
WAIKATO JOURNAL OF EDUCATION
}

\author{
TE HAUTAKA MĀTAURANGA O WAIKATO \\ VOLUME 13, 2007
}

Creative Research In The Arts: Introduction To The Special Section KAREN BARBOUR

Art Works As A Re-Presentation Of Research

JILL SMITH

Through The Eye Of A Needle: The Story Of Two Academics' Use Of Fabric Crafts To Make Defiant Messages

BELLA GRAHAM AND JOYCE STALKER

Researching Collaborative Artistic Practice

KAREN BARBOUR, DONN RATANA, CHERI WAITITI AND

KIM WALKER

Reflective Practice: Dance-Making And Image Narratives DEBBIE BRIGHT

Reflections Through Invisible Glass Walls: Self-Study Of Teacher

And Artist

COLIN GIBBS

The Youthanasia Of Dance: A Research Nexus Diary Of Dance

In Tertiary Education

LINDA ASHLEY

Interweaving Philosophies Of Dance Teaching And Dance-Making: What Can One Practice Teach The Other?

ALISON EAST

Aesthetics And Didactic Intention: The Meeting Place Of Beauty And Information Transmission In The 2006 Community Theatre Production Of Swamp Treasures JOHN G. DAVIES

Experiential Learning: A Narrative Of A Community Dance

Field Trip

RALPH BUCK AND KAREN BARBOUR 
Creative Teaching Or Teaching Creatively? Using Creative Arts Strategies In Preservice Teacher Education

ROBYN EWING AND ROBYN GIBSON

A Case Study: Issues Of Culture, Diversity And Difference In Art

Education In New Zealand

JILL SMITH

Music To Measure: Symbolic Representation In Children's Composition

CLARE HENDERSON

Safe To Speak? A Teacher's Story Of One Child's Apparent 'Liberation' And 'Transformation' Through The Security Of Role

VIV AITKEN AND SHAY COWLEY

Captured Voices In Primary School Art Education

GRAHAM PRICE

Developing Non-Verbal Ways Of Knowing In Dance: Collaborative School/University Action Research CLARE HENDERSON, DEBORAH FRASER, SUE CHEESMAN AND SHIRLEY TYSON

Education's 'Inconvenient Truth’: Persistent Middle Class

Advantage

MARTIN THRUPP

Reflecting On The Development Of A New School Subject: The Development Of Technology Education In New Zealand ALISTER JONES 


\title{
SAFE TO SPEAK? A TEACHER'S STORY OF ONE CHILD'S APPARENT 'LIBERATION' AND 'TRANSFORMATION' THROUGH THE SECURITY OF ROLE
}

\author{
VIV AITKEN AND SHAY COWLEY
}

School of Education, The University of Waikato

\begin{abstract}
The following article arose out of conversations between the authors, Shay Cowley, a second year student at the School of Education, The University of Waikato, and Dr. Viv Aitken, who lectures in Drama in Education at the same university. Shay contacted Viv to tell her about the successful drama unit she had taught on her first year teaching practicum and, in particular, to report the apparent 'transformation' that had occurred for one student in the class (referred to here as 'Kate'). Through continued discussion about Shay's experience, a decision was made to share her story and to position this within related theory on the transformative potential of drama. In terms of methodology, then, the article emerges from practitioner reflection: in this case, the anecdotal reflections of an emergent teacher. The student's narrative is then deconstructed and the anecdotal material is used as the basis for the exploration of hypothetical questions which are seen as having relevance and importance in the field of drama education.
\end{abstract}

\section{KEYWORDS}

Drama education, Role, Student teacher practicum, Transformation, Reflection

\section{INTRODUCTION}

It should be emphasised that in this article we approach the notion of 'transformation' from an educational rather than a therapeutic perspective. Although there are inevitable and important connections between these two contexts, particularly in this story which deals with a student with a recognised difficulty, this was not a situation in which drama was used consciously as a therapeutic tool. It may be that, as educators, we should take more cognisance of the therapeutic aspects of drama. This much is implied later in the article, where Neelands" concept of learners as "human becomings" rather than human "beings" is discussed (Neelands, 2004, p. 53). Nevertheless, the starting point of this exploration is educational rather than therapeutic and so it is within this context that the work is positioned.

We begin this article with the classroom narrative written by Shay, with Viv's support. This part of the article tries as much as possible to maintain the authentic, enthusiastic, idealistic and, at times informal 'voice' of this student teacher. In the second part of the article, Viv adds commentary and theoretical context to Shay's story and makes a case for further study of the transformative potential of drama. 


\section{Viv Aitken and Shay Cowley}

The authors wish to thank Kate, her family, teacher and supporting staff for allowing us to tell this story.

\section{SHAY'S NARRATIVE}

When I ran into Kate (not her real name) at the supermarket, she was standing in the yoghurt aisle. She was behaving just like a typical 12-year-old girl, yelling at her brother and hitting him on the arm. I almost did a double take because this was not the Kate I recognised from a few months before when I had been a student teacher on practicum in her class. "Hello Kate," I said, and at that moment she froze, curled up and withdrew. She put her two hands together in front of her body - just the fingertips touching - and she refused to speak except in a tiny whisper. This was more like the Kate I'd seen in class.

Kate has been identified as an elective mute. She chooses not to speak. The reasons for this are not clear and are not the focus of this article. However, the family point out that Kate is chatty and sociable at home and that she did speak normally and had friends at a previous school in a different town, so it appears the issue could be school-related. When I arrived on practicum in her class last year I remember the teacher told me: "You probably won't have any luck with her." She said not to get upset if Kate wouldn't talk to me. She told me that Kate had exhibited this problem since she first started at the school and that there would be a teacher aide working with her from time to time.

This classroom narrative tells the story of how Kate came out of herself through drama and how I, as a trainee teacher, went from being uninterested in drama to being someone convinced about its potential in the classroom.

My own exposure to drama before this practicum was limited to the module I completed at the University of Waikato. Over six weeks we learnt about process drama, improvisation and drama conventions to use in teaching. The main thing I took away from the module was the idea that you do not need a script. Before this module I always thought drama was quite a strict subject. You had to stand the right way and say the right thing at the right times. My placement school had no drama while I was there and I had not studied drama during my own schooling. Because of this, while I thought drama was an entertaining subject I was sceptical about its value in education. My experience with Kate has left me enlightened about the value drama can have and keen to learn more.

When I first arrived in the classroom, I noticed Kate sitting by herself while all the other students interacted with one another. On occasion, a student would go and sit with Kate and attempt to make conversation with her. However, they would often move off to interact with the others again within a short period of time, possibly due to frustration at Kate's lack of conversation. Kate was very selective about whom she would talk to: only a couple of other students, the teacher and her teacher aide were able to have short, whispered conversations with her on a one-toone basis. While all the students were very supportive of and patient with Kate, she was often left on the outskirts of any social or classroom activities which made it quite difficult for her to get the full benefit from lessons or to develop any meaningful relationships with her peers. 
The teacher was extremely patient with Kate but felt that nothing seemed to be working. Prior to my starting practicum she had offered Kate some kind of incentive if she made an effort to talk to me. Kate got to choose what this would be. She decided on a DVD afternoon where the whole class could watch a movie. I think this incentive motivated Kate to make the initial effort to talk to me one-onone, as she had done with previous student teachers.

The teacher's incentive resulted in Kate being prepared to talk to me. She waited until the end of the first day when all the other students had left and came up to my desk. In a whisper she said good afternoon then made a run for the door. I was pleased that we'd got this far on my first day. I didn't imagine how much further we were about to go.

I was planning a drama unit with a murder mystery theme. For this, I worked with the Year $7 \mathrm{~s}$ in the class (approximately 18 children including Kate). All students were given a role with some basic guidelines to help them form the personality of that role, although I designated which character was the killer. All students chose their roles by randomly pulling a name out of a hat. We used various drama conventions and strategies including 'freezeframes', 'hotseating', 'news reports', 'teacher in role' and 'role on the wall' to explore the roles and expand the storyline. I felt that the unit was successful for the children. All the students fully participated, including Kate.

Kate had the role of the widow, a main suspect in the murder mystery. She was shy, but not resistant to selecting the role, and I remember she smiled when I said we were doing a murder mystery. Early on in the drama we did an impromptu courtroom scene with the widow as chief suspect and the children in role as lawyers putting the case for and against her guilt. At first Kate sat at the back of the group, using her facial expression and body language to express her character. I saw her frowning and shaking her head when she disagreed with something one of the lawyers was saying. At one point she folded her arms, put her chin down and stomped her feet. At other times she would smile broadly. Her facial expressions were bigger and more expressive than her usual non-verbal interactions and she was clearly in role.

At the start of the next session, the children were asked to give a brief introduction to their character by speaking to the rest of the group in role. Kate watched as the first person did so, then put up her hand to volunteer. She looked a bit hesitant, so I chose someone else to go next. After watching the second child, Kate put her hand up again. She was sitting close beside me so I bent down and asked: 'Do you want to go next?' She just nodded. I wanted to give her a go, though I assumed she would just get up there and freeze, so I told the group: 'Kate is going next'. The rest of the children went very quiet and watched. Kate held the card up close to her face and started to speak in her usual whispering voice, but she was in role and she was speaking to the whole group. It was a big moment. Even the teacher put down what she was doing to watch and listen to Kate. She spoke for just a few seconds. At the end she turned and faced the whiteboard behind her. She was grinning and her face was bright red. Everyone clapped and cheered. The teacher called Kate over to tell her how proud she was. Then Kate sat down and we carried on the exercise with the other children. 


\section{Viv Aitken and Shay Cowley}

After that day we did drama about six more times. Each time we did role work, Kate was able to speak in role to the other children in her group. As far as I know, she had never spoken to groups other than her close friends. When talking in role the volume of her voice got a bit louder too, so that it was like a 'quiet talk' instead of a whisper. I also noticed her moving her chair closer to fit closer in with the groups, rather than sitting right back with her chair turned away as she usually did. In between the drama activities Kate continued to refuse to speak.

Perhaps the most exciting day was my final day of placement, at the close of the drama unit. To wrap up, I'd got the Year 7s to write up the murder mystery story as a news report. They were to perform these to the Year 8s. Kate's group was the second of the four groups. Kate was the 'anchorwoman' (she had chosen this key role herself). I went to check in with her to see if she was comfortable and she indicated that she was and she would try it. Her group set up and she sat behind her 'news desk' at the front of the class. Kate had a set of bullet points in front of her and she listened as the group played the little 'news' theme they had created, using body percussion and voice. Kate was the first to speak. I was stunned. She spoke in a whisper but she also used her hands and face to express herself: "Welcome to the news, tonight's top story is ..." She did really well. She had to say goodbye at the end as well and she did that a bit louder.

After that success, the teacher and I thought we could push Kate a bit further. We had been working on class speeches and, not surprisingly, Kate had refused to deliver hers out loud. When we asked her whether the anchorwoman might read a certain little girl's speech, she hesitated then said 'yes'. We told the class that the anchorwoman had a speech to read. Kate went and grabbed it from her desk and stood up in front of the class. I was really proud as Kate, in role as the anchorwoman, read out the whole speech, still in a whisper of course but she did it! Then we pushed her again and said: 'Can you read it again in a 'speaking' voice instead of a whisper?' I thought it was a bit tough of us to do that but she did it. She stared at us for a bit. She didn't look too impressed but the other children were urging her on and she nodded and started again. This time you could hear every word and she was even using some of the conventions of speech, like emphasis. I couldn't tell you what the speech was about because I didn't care what she was talking about. I was just watching her speak! She was so proud of herself. Her teacher aide came in just at the end of the speech and praised her for doing so well. And that was my last day.

I went back to visit the class at the end of term four. It was about a month later, not long after I had seen Kate at the supermarket. As soon as I walked in I noticed that Kate was once again sitting on the outskirts of the group she was in and hunched over. When I mentioned this to the teacher, she said that Kate had withdrawn again and was no longer speaking to anybody but the select few she had been speaking to throughout the year. She was feeling frustrated by this and felt that Kate wasn't making any progress. I wondered if the teacher had done any more drama with Kate and I asked her what they'd been up to. It sounded as though the teacher had been really busy. The whole class had shifted to a new classroom, they'd had ministry audits to prepare for and, with the end of term, she had had other assessments and units to tie up and she had not been able to use drama since I 
was there. This made me feel sorry for Kate and for the teacher, as a lack of time and opportunity meant that they had not been able to draw on drama, the tool we had found to allow Kate to confidently communicate.

\section{COMMENTARY, FURTHER QUESTIONS AND TENTATIVE CONCLUSIONS}

Shay's story about Kate's experience in drama is compelling. At first sight, it appears to stand as clear testament to the efficacy of drama as a medium for transformation, at least for this particular child. And this story is not an isolated one. As Neelands (2004) states, "localised testaments to miracles happening in, or as a result of experiences in drama education [are] too numerous to mention here" (p. 47). While being rightly inspired by the apparently miraculous qualities of Kate's story, we also appreciate that we must be careful not to overstate or oversimplify the case.

Neelands (2004) cautions us against an evangelistic belief that drama has some kind of magic power; that drama can in and of itself produce a miracle or a "profound and new change in a student" (p. 47). As he asserts, "It is what we do, through our own human agency, with drama that determines the specific pedagogy and specific powers that these examples of rhetorical elision ascribe to the idea of drama itself" (Neelands 2004, p. 48, emphasis in original). For example, Shay's narrative describes how Kate withdrew back into herself between the drama sessions and also after Shay departed from the classroom and drama was discontinued. It is tempting, particularly as an advocate for drama, to state that drama was the key, and without it, Kate regressed. However, it may be too simplistic to portray drama in and of itself as the miracle that cured Kate.

In our view, there was a combination of things that may have been important for Kate. First of all, there is the part played by Shay herself. Shay is a sparky and bright student who impressed her teaching associate with her maturity and natural talent for teaching. Indeed, the teacher described Shay as having teaching skills way beyond those expected of a first year teacher. Shay's narrative does not pay attention to her own skills but it is likely that these were a significant factor in Kate's transformation. Apart from any specific pedagogical skills, Shay also appears to have formed a strong relationship with Kate. Recent research (Bishop \& Berryman, 2006; Noddings, 2003) has confirmed the intrinsic significance of relationships in the classroom. It is possible, then, that the strong, trusting teacherstudent relationship may have been just as important in Kate's transformation as the choice of drama as a strategy.

There may well have been pragmatic issues at play here too. Shay was an extra teacher in the class. As such, she was mainly working with small groups and so had the time to give Kate a higher level of one-to-one attention than usual, even taking into account the role of the part-time teacher aide. The research is inconclusive as to how the ratio of student-teacher numbers impacts on student achievement since it is so hard to separate group size from other factors impacting on student learning (Hoxley 2000; Pedder, 2006). However, extra teacher attention may have been a factor in this case. The fact that Shay's was a new face may also have been 


\section{Viv Aitken and Shay Cowley}

significant. Who can tell how much Kate's speaking arose from novelty value or an eagerness to please the new teacher? Furthermore, we cannot ignore the fact that the classroom teacher offered Kate a very attractive incentive to get her to speak to Shay. We are even told that that similar incentives had worked on previous occasions with previous student teachers, although we also note that Kate went on to do much more than she needed to do to earn the incentive.

It is also important to note the broader social-cultural context in which Kate's transformation occurred. The narrative states that the other children in the class were supportive of Kate when she was speaking in role, although we are also told that at other times Kate was isolated socially within the class. Peer relations are known to be critical factors for a child's self-confidence and ability to learn (Newcomb \& Bagwell, 1996), so the support or otherwise of the children must also be acknowledged as factors in Kate's story. Kate's story extends beyond the classroom too, in that she enjoys the long-term support of her teacher aide, health professionals, psychologists and her family. None of these inputs is mentioned in the narrative but all will clearly have played their part in the events described.

Perhaps, as Neelands (2004) suggests, what really feeds transformations in learners is not a particular strategy, in this case drama, in isolation, but how this strategy is used in conjunction with a broader classroom-community-home context that embraces and expects change. It could be argued that one of the biggest things Shay did for Kate was to keep giving her opportunities and to maintain expectations that Kate could succeed. Although at times the narrative reveals moments where assumptions are made about Kate, (e.g., where Kate's refuses 'not surprisingly' to give her speech), Shay's actions as teacher demonstrated a continued commitment to giving Kate an opportunity. Rather than taking measures to accommodate Kate's mutism, such as avoiding giving Kate a main role, Shay treated her like every other child in the class. This signalled to Kate and everyone else that Shay had faith in her potential to grow and change. Kate's lack of speech was not accepted as a given.

Neelands (2004) argues that it is this kind of mindset that really characterises transformation in drama. Indeed, he goes so far as to argue for a wholesale reconception of pedagogy in which the expectation of personal transformation is there in every classroom, not only the drama classroom, and for every child, not only those with a recognised disorder or difficulty to overcome. Neelands suggests that in 'a pedagogic context that stresses 'becoming', that sees students as human 'becomings' rather than human 'beings', that views human potentiality as a project rather than as an essentialised and contained given, 'miracles' are not the exception but the rule" (p. 53).

Having acknowledged the importance of the bigger picture, and bearing in mind Neelands' caution (2004) about evangelising, we would nevertheless tentatively suggest that there was something about the use of drama, specifically the element of role that proved particularly useful to Kate. It is possible that, for a child struggling with self-expression, the opportunity to take on a role provided a place of safety, an opportunity to be someone else, someone who could use her voice without the same struggles. The fact that Kate could not deliver her class speech as herself but could move into role as the anchorwoman and deliver 'a certain little 
girl's speech' certainly suggests that this may be so. Drama has long been characterised as the opportunity to 'walk in someone else's shoes' (Heathcote, Johnson \& O'Neill, 1984) and much has been written about how this process can build children's capacity for empathy (Neelands, 2002; O'Connor, 2006). Is it also possible that, for some people, the most important thing about walking in someone else's shoes is the opportunity for being liberated from their own? Is it possible, indeed, that working in role can liberate people to the point that they may gain capacity or access skills and competencies they are unable to access as their everyday selves? In Kate's case, the skills accessed were specifically related to drama-voice which is, after all, a technique of drama itself - but is it possible that participants can access non-drama skills through the medium of drama? These questions are important and exciting and carry huge implications, not only for therapeutic practice but also for pedagogy in general.

While it is beyond the scope of this article to answer these questions, it may be possible to consider a theoretical context to suggest why role may have this potential. Much has been written about how drama offers a second, alternative reality alongside the known reality of the classroom (Edmiston, 2003; Morgan \& Saxton, 1987). Indeed, it is the presence of this second reality running alongside the known world, and the participants' ability to shift between the two realities (metaxis), that is seen by many commentators as the core value of drama (Boal, 1995; Edmiston, 2003; O'Connor, 2006). Drama tasks occur in a fictional frame and it is because of this that they have a special quality. This is what makes drama empowering and this is also what makes it safe. Bolton (2003) puts it this way,

At a visible, concrete level [the drama tasks] demand normal intellectual application from whoever is carrying out the task, but at a subsidiary level there is a 'no penalty' awareness felt by the doer, a sense of freeing the individual, so that they may find themselves 'caught off guard' into identifying skills they did not know they had, into seeing some aspect of themselves in a different light, into revising the way they habitually think about themselves. They learn these new things privately, safely. (p. 136)

For many children, the 'no penalty zone' of drama is what makes it safe to take risks, to shake off the knowledge and power structures of the traditional classroom environment, and to act without fear of consequences occurring in the 'real' world. Perhaps for Kate, the safety of drama contributed to her willingness to speak aloud while in role.

Since this article is based on a single narrative rather than any kind of comparative research, we cannot claim any concrete or measurable findings. We can, however, draw on the striking events described in this narrative to ask questions that may, in future, be more systematically investigated. The urgent task of drama researchers, as Neelands (2004) suggests, is to take stories of transformation such as this one and move them beyond their current status as 'hero narratives' or evangelistic symbols of hope for an under-appreciated art form. It is possible, we argue, for creative researchers to move towards a more meaningful theoretical terrain "which might both support the possibility of personal and social 


\section{Viv Aitken and Shay Cowley}

transformings through drama and also provide a set of heuristics for discussing the local context and conditions in which these transformations are claimed" (Neelands, 2004, p. 50). Kate's story is fascinating for the questions it opens up for future investigation. For example, is it possible to use drama as a tool with special needs or insecure students, or indeed any student, to develop new skills and competencies? What evidence is there that students will carry any skills and competencies accessed while in role back into their everyday life? How can they be helped to do this? What other social and pedagogical conditions need to be in place for drama to effect transformations of this kind? Further, as researchers how can we carry out creative research in the arts so that narratives of transformation can be placed in a broader pedagogical context and, therefore, gain credibility and theoretical mana?

\section{AFTERWORD}

Since this article was first written, Shay has returned to facilitate further sessions in drama with the children in this class, including Kate. Shay reports that the follow up sessions were fun and that all children, including Kate, experienced some success in terms of the desired learning outcomes. However, Shay also commented that Kate seemed less involved in the drama this time and that she would only participate in her 'whispering voice'. The fact that narrative does not have a conveniently miraculous ending only reinforces the points made earlier in this article: the need, first of all, to treat transformational narratives with balance and within context, whilst acknowledging that something of significance may well have occurred, and the need also for a heuristics of transformational experiences so we might begin to understand the conditions required for genuine and enduring drama 'miracles' to occur.

\section{REFERENCES:}

Boal, A. (1995). The rainbow of desire: The Boal method of theatre and therapy. New York: Routledge.

Bolton, G. (2003). Dorothy Heathcote's story: Biography of a remarkable drama teacher. Stoke on Trent, UK: Trentham Books.

Bishop, R., \& Berryman, M. (2006). Culture speaks: Classroom relationships and classroom learning. Wellington, New Zealand: Huia.

Edmiston, B. (2003). What's my position? Role, frame and positioning when using process drama. Research in Drama Education, 8(2), 221-230.

Heathcote, D., Johnson, L., \& O'Neill, C. (1984). Dorothy Heathcote: Collected writings on education and drama. London: Hutchinson.

Holland, C., \& O'Connor, P. (2004). Like writing off the paper: Report on student learning in the arts. Wellington, New Zealand: Ministry of Education.

Hoxley, C. (2000). The effects of class size on student achievement: New evidence from population variation. The Quarterly Journal of Economics, 115(4), 1239-1285.

Morgan, N., \& Saxton, J. (1987). Teaching drama: A mind of many wonders. London: Hutchinson Education. 
Neelands, J. (2002, September). The space in our hearts. Paper presented at the 2nd International Theatre and Drama Education Conference, Athens, Greece.

Neelands, J. (2004). Miracles are happening: Beyond the rhetoric of transformation in the Western traditions of drama education. Research in Drama in Education 9(1), 47-56.

Newcomb, A. F., \& Bagwell, C. (1996). The developmental significance of children's friendship relations. In W. M. Bukowski, A. F. Newcomb \& W. W. Hartup (Eds.), The company they keep: Friendship in childhood and adolescence (pp. 289-321). New York: Cambridge University Press.

Noddings, N. (2003). Happiness and education. New York: Cambridge University Press.

O'Connor, P. (2006). Process drama and learning for now. Mindnet 5. Retrieved October 10, 2006, from www.mindnet.org.nz

Pedder, D. (2006). Are small classes better? Understanding relationships between class size, classroom processes and pupils' learning. Oxford Review of Education, 32(2), 213-234. 